\title{
Antecedent And Consequent Of Altruistic Professional Behavior Of Catholic Religious Education (CRE) Teachers In South Papua
}

\author{
Donatus Wea ${ }^{1}$, Fakhruddin ${ }^{2}$, Y.L. Sukestiyarno ${ }^{3}$, Titi Prihatin ${ }^{4}$ \\ \{romodonwea@yahoo.com ${ }^{1}$, fakhruddin@mail.unnes.ac.id ${ }^{2}$, sukestiyarno@gmail.com ${ }^{3}$, \\ titi.prihatin.oce@gmail.com ${ }^{4}$ ? \\ Catholic Academy of Santo Yakobus Merauke, Papua, Indonesia, $081247719057^{1}$ \\ Graduate School Universitas Negeri Semarang, Indonesia, $082133873456^{2}$, \\ Graduate School Universitas Negeri Semarang, Indonesia, $0818241519^{3}$, \\ Graduate School Universitas Negeri Semarang, Indonesia, $087855021320^{4}$
}

\begin{abstract}
This article discusses the impact of spiritual and emotional intelligence on the performance of Catholic Religious Education (CRE) teachers in South Papua, with the intervening variable is altruistic professional behavior. Three hypotheses are tested using structural equation modeling. The analysis results show that the three hypotheses proposed are all proved to be significant. The findings indicate that work and achievement are not only due to the financial gain, but there are more important things: the existence of values that are believed. These values are a set of principles that is held firmly by someone to achieve various goals in life and becomes the spirit of dedication. The selflessly dedication can encourage the teachers of CRE to carry out their role as transformers, facilitators, motivators, learning planners, and learning inspiration for their students. Altruistic professional behavior can be practiced as an educational human resource instrument to educate students in this country.
\end{abstract}

Keywords: Spiritual Intelligence, Emotional Intelligence, Altruistic Professional Behavior, Catholic Religious Education Teacher Performance.

\section{Introduction}

Teacher is an important element in the world of education because teacher becomes an integral part of educational resources that greatly determine the education success. This is mandated in the Law of the Republic of Indonesia, Number 14 of 2005 on Teachers and Lecturers explaining that teachers are learning agents who become facilitators, motivators, boosters, learning planner, and learning inspiration for students. The affirmation of the law requires the presence of teachers who have adequate performance and competence.

Teacher's performance and competence have the main responsibility in the orientation of transforming students from being ignorant to being independent and from being unskilled to being skilled. In order to do that, teachers should apply learning methods that can prepare students to be active and knowledgeable always absorbing and adjusting new information by thinking, saying, digging, creating, and developing certain behaviors in solving problems with students' lives[1]. The same thing also emphasized by Widoyoko and Rinawati that teachers who have good performance will be able to foster enthusiasm and motivation for students to 
learn better, which in turn will improve the quality of learning[2] . So, performance is a form of someone's behavior with achievement orientation. The form of related behavior is the teacher activity in the learning process, namely how the teacher's learning plan in carrying out learning activities and assessing learning outcomes[3] . According to Kapur, teacher plays the main role among the various inputs that determine the quality of education. The most dominant factor that affects the teacher teaching quality is teacher performance[4] .

This study was conducted on CRE teachers in South Papua (Merauke, Boven Digoel and Mappi regency). In the midst of real economic condition surrounding the most teachers' lives, CRE teachers who were the subjects of this study remain in appalling condition such as they received the compensation far below the Regional Minimum Wage standard. The question that arises is, what are the strengths for CRE teachers so that they continue to survive in carrying out their duties as teachers, namely providing services and assistance to students? Apparently they have altruistic behavior. According to Meyer, Roberts and Barsade, altruism is the opposite of selfishness[5]. An altruistic person cares and wants to help even if there is no advantage offered or there is no hope that he will get something back. The study of Feng and Guo shows that altruistic behavior is needed in organizations, and organizations will get double results if employees have altruistic behavior especially during an economic recession[6]. Feng and Guo state that altruistic behavior can have a positive impact individually, increase feelings of physical and psychological belonging, create wider social networks, increase career opportunities, and reduce loneliness. Myers in his study (Barasch, Levine, Berman, \& Small, 2014) explains that altruistic behavior has several aspects which are empathy, voluntary, and sincerity to help others without expecting any rewards from them. The interests of others are the focus and priority of service from people who have altruistic behavior[7]. Furthermore, Myers explains that a person's altruistic behavior is actually influenced by three factors which are situational factors, interpersonal factors and personal factors. Situational factors include a description of the situation, the urgency of time, moods, rewards obtained, direct observation on the need for help and considerations that allow someone to take an altruistic action[8].

Personal factors are factors originated inside the person, which include the feelings and religiosity of the person. Some social psychology studies concluded that in addition to the factors proposed by Mayers, a person's altruistic actions can also be influenced by many other factors, which are the presence of others, environmental conditions, time pressure, personality factors, mood, self-distress and empathic feeling[9]. Employees with high altruistic behavior will have extra and high-performing role behaviors[10].

Research finding of Srivastava explains that spiritual intelligence in employees has a positive correlation with altruistic behavior[11]. Spiritual intelligence is a series of adaptive mental capacities based on reality aspects of non-material and transcendent, especially those related to the origin of one's existence, personal meaning, and a high level of awareness. Spiritual intelligence is believed to be an intelligence that is able to function intellectual intelligence and emotional intelligence effectively[12].

Spiritual are things that concern human values non-material in the soul and heart of man, such as kindness, truth, beauty, pure of love, spiritual and psychological[13]. In religion, these qualities concern humanity which is non-material, such as consistency, humility, effort and submission, sincerity, totality, balance and integrity. Iskandar argues that spiritual intelligence is an individual's ability to manage values, norms and quality of life by utilizing the power of the subconscious mind or conscience (GOD SPOT) [14]. In this case, someone who has high spiritual intelligence, will be able to manage values/norms and to utilize the power of his subconscious mind. 
$\mathrm{H}_{1}$ : There is a positive and significant influence of spiritual intelligence on the altruistic professional behavior of CRE teachers.

Petrides and Furnham state that emotional intelligence is the ability to feel, understand and effectively apply emotional power and sensitivity as a source of energy, emotion, connection and human influence[15]. Aspects of emotional intelligence include the introducing emotions, managing emotions, motivating oneself, getting to know other people's emotions, and improving personal skills-the ability to manage oneself.

According to Brackett, Rivers, \& Salovey, emotional intelligence is an individual's intelligence in recognizing, understanding, and controlling personal emotions, as well as the ability to feel and to understand the feelings of others, to guide the mind to make the best decisions[16]. Furthermore, Brackett et al., explain that emotional intelligence has three aspects such as aspects of emotional competence which consists of self-awareness, selfcontrol, and self-motivation, aspects of empathy, and aspects of social skills. Aspects of empathy and social skills can be integrated into one competency, namely social competence[17].

Sensitive and significant effect on Organization Citizenship Behavior (OCB) measured through empathy, intrinsic motivation, and self-control. Organization Citizenship Behavior is extra individual behavior which is not directly or explicitly recognizable in a formal work system, and can improve the effectiveness of organizational functions. Tambe in his research found a significant relationship between emotional intelligence and aspects of organizational citizenship altruism behavior, explaining that the effectiveness of the empathy aspect lies in the top priority[18].

$\mathrm{H}_{2}$ : There is a positive and significant influence of emotional intelligence on the

altruistic professional behavior of CRE teachers.

The theory of exchange relations in an organization can be divided into two forms that are the relationship of economic exchange and social exchange relations. The Social Exchange Theory proposed by Cook, Cheshire, Rice, and Nakagawa, states that one's actions are not always measured by economic benefits, but by other things such as happiness, helping others, willingness to sacrifice (time, energy and material) for the benefit and happiness of others, and to feel satisfaction when they are consciously and responsibly involved in helping others[19]. Such actions by sociologists are called altruistic behavior.West in the article "An Alternative Perspective Based on Buddhist Theory" defines altruism as the urge to help other and selfishness as the urge to help yourself [20]. In general, altruistic behavior is voluntary action by a person or group of people to help others without expecting anything in return[21]. Batson in his study explains that people who have altruistic behavior are people who really have an interest that is not selfish in helping others. Individuals who have altruistic behavior prefer to satisfy others rather than satisfy their own needs. Their satisfaction is obtained after doing things that can help others[22].

From the description above, it can be concluded that altruistic behavior is a behavior that cares and likes to help others voluntarily without expecting reward. The altruist's will focuses on motivation to help others or the intention to do something selflessly, in the form of moral provisions. This act is a pure character in many cultures and is the core of many religions. Altruistic behavior is conducive to cooperate within the organization. An employee with altruistic behavior will give more contribution to the organization or to defeat himself, which is not only useful for improving his own abilities, but also greatly influence the effects and synergy. 
In relation to professional educators, the competence of educators refers to rational performance or actions that meet certain specifications in carrying out educational tasks. Based on these explanations, the third hypothesis proposed is:

H3: There is a positive and significant effect of altruistic professional behavior on the

performance of CRE teachers

Based on the explanation above, this article discusses the problem of CRE teachers' performance in South Papua with intervening variable that is altruistic professional behavior, and antecedent variables that are spiritual intelligence and emotional intelligence.

\section{Methods}

This study uses primary data obtained through a questionnaire. CRE teachers in southern Papua were choosen as an object of this study because there are still many CRE teachers have not received moral and economic attention. Samples of $220 \mathrm{CRE}$ teachers were taken from the population that were 320. The sample was determined by purposive random sampling technique. Since many respondents did not give an answer, 186 observation units were declared valid.

Variable measurement used Likert scale from 1 to 7 , with a score of Strongly Disagree (Score 1) to Strongly Agree (score 7). The spiritual intelligence scale consists of 5 indicators with reference to aspects of spiritual intelligence proposed by Agustian, which include: feelings of gratitude; frequency of prayer; affection and love; awareness of the mission call and longing for more meaningful life[23]. The emotional intelligence scale consists of 4 indicators with reference to the aspects of emotional intelligence proposed by Gayathri \& Meenakshi, which include: Self-awareness, Self-control, Self-motivation, and Empathy and Social skills[24]. The altruistic professional behavior scale consists of 4 indicators with reference to the concepts of Robbins, which include: Impulse to do good, Willingness to sacrifice selflessly, Selflessness, and Satisfaction in helping others[25].

The performance of CRE teachers consists of 4 indicators with reference to aspects of teacher performance proposed by Dessler, which include: Planning the learning process, Implementation of the learning process, Assessment of learning outcomes, and teacher professional development[26]. The hypothesis testing used Structural Equation Modeling (SEM) as a tool to test the relationships among variables that are complex and to obtain a comprehensive picture of the overall model. AMOS is the software usedin this study.

\section{Results and Discussion}

\subsection{Analysis of Dimension, Reliability and Validity}

Exploratory Factor Analysis (EFA) is a factor analysis method to identify correlation among manifest variables in construct building. The data can be concluded to be reliable and valid so the next analysis can be continued.The result explains the loading value of each variable towards its indicators. On spiritual intelligence variable, the indicator of love and affection occupy the highest position with the score of .743. It shows that love is the main form of spiritual intelligence of CRE teachers and becomes the basis and the soul of the other aspects. This statement is confirmed by Jesus Himself in His words "Love the Lord your God 
with all your heart and with all your soul and with all your strength and with all your mind, and love your neighbor as yourself." (Luke 10:27).

On emotional intelligence variable, self-control earns the highest score from all the indicators of this variable, with 0.753 earning point. It is because self-control is an expression of self-conquest for the good of others. Self control is the recognition of oneself that one's presence is for the good of others. In other words, self-control is a further embodiment of one's love, as St. Paul says "Therefore, as God's chosen people, holy and dearly loved, clothe yourselves with compassion, kindness, humility, gentleness and patience." (Col.3:12). Selfcontrol behavior as a form of love is explicitly affirmed by the Apostle Paul in his letter to the Corinthians (1 Corinthians 13: 4). "Love is patient, love is kind. It does not envy, it does not boast, it is not proud".

On the altruistic professional behavior variable, the willingness to sacrifice selflessly gets the highest score of .735 compared to other indicators. It is because this indicator is also the manifestation of teachers' commitment as disciples of Christ, who must surrender themselves totally because of the love for the good of others. It is based on the God's word "Greater love has no one than this: to lay down one's life for one's friends" (John 15:13).

On the CRE teachers' performance variable, learning process planning scores the highest 0.797 from the other indicators, because planning determines the result. Those who make careful and regular planning will reap the satisfying result. It is based on the God's word "Be on guard! Be alert! You do not know when that time will come" (Mark 13:33).

Goodness of Fit Model. The results of testing with Amos, is concluded that the resulting line model can be stated fit because it is in the required cut of value range, only Adjusted GFI (AGFI) and Normed Fit Index (NFI) are in marginal area. This condition according to Hair, Black, Babin, Anderson, \& Tatham, is stated not to be a problem because it is still in the range of close to 1 (one) [27].

In testing SEM assumptions, that the data have been stated normal in both the multivariate and univariate dimensions, the data are also free from both multivariate and univariate outliers. Likewise, the data are also free from the elements of multicollinearity and singularity. Thus, the full SEM model can be stated free from classical assumptions. It, then, can be concluded that the model can be used for the analysis of testing hypotheses.

Hypotheses Testing. The 3 hypotheses testing as shown in the table 1.

Table 1. Regression Weights

\begin{tabular}{|c|c|c|c|c|c|}
\hline \multirow{2}{*}{ Causality Relations } & \multicolumn{2}{|c|}{ Estimate } & \multirow{2}{*}{ S.E. } & \multirow{2}{*}{ C.R. } & \multirow{2}{*}{$\mathrm{P}$} \\
\hline & Unstandardized & Standardized & & & \\
\hline $\begin{array}{l}\text { Emotional Intelligence } \rightarrow \\
\text { Altruistic Professional Behavior }\end{array}$ & .287 & .249 & .105 & 2.726 & .06 \\
\hline $\begin{array}{l}\text { Spiritual Intelligence } \rightarrow \text { Altruistic } \\
\text { Professional Behavior }\end{array}$ & .330 & .273 & .110 & 3.003 & .03 \\
\hline $\begin{array}{l}\text { Altruistic Professional Behavior } \rightarrow \\
\text { CRE Teachers' Performance }\end{array}$ & .575 & .439 & .122 & 4.699 & $* * *$ \\
\hline
\end{tabular}

The first hypothesis testing, the influence of Spiritual Intelligence towards Altruistic Professional Behavior is proved to be significant with CR 3.135 and sig. $t=.002<.05$. This study explains that the higher the spiritual intelligence of CRE teachers, the higher the 
altruistic professional behavior. This study supports the study of Van Scotter, which explained that employees' spiritual intelligence has a positive correlation with their altruistic behavior [28], and the study of Iskandar, which stated that someone who has got high spiritual intelligence, will be able to manage values and norms and use the power of his subconscious $\operatorname{mind}[29]$.

The second hypothesis testing, the influence of Emotional Intelligence towards Altruistic Professional Behavior is proved to be significant with CR 3.988 and sig.t $=* * *<.05$ smaller. This study explains that the higher the emotional intelligence of CRE teachers, the higher the altruistic behavior. It supports the study conducted by Elham Sahafi et al., that emotional intelligence can improve empathy, intrinsic motivation, and self-control which are included as extra-individual behaviors that cannot be formally recognized directly[30]. This intelligence can improve the effectiveness of organizational functions. This study also supports Tambe, which explained that organizational citizenship behavior is measured by empathy, which becomes the top priority in selfless sacrifice[31].

The third hypothesis testing, the influence of Altruistic Professional Behavior towards CRE Teachers Performance is proved to be significant with CR 3.821 and sig.t $=* * *<.05$. This study states that the higher the altruistic professional behavior, the higher the CRE teachers performance. This result supports the study of Srivastava, which stated that there is a positive relationship between employee loyalty and caring for others selflessly, and it is able to create greater employee retention and positive loyalty to performance. In general, employees with greater altruistic behavior will make more effort and show better job performance[32].

\section{Conclusion}

The analysis results show that the three hypotheses proposed are all proved to be significant. The findings indicate that work and achievement are not only due to the financial gain, but there are more important things: The existence of values that are believed.

These values are a set of principles that is held firmly by someone to achieve various goals in life and becomes the spirit of dedication. The selflessly dedication can encourage the CRE teachers to carry out the role as a transformer, facilitator, motivator, learning planner, and learning inspiration for their students. Thus, the concept of altruistic professional behavior can be practiced as an educational human resource instrument to educate students in this country. The results of this study open the possibility for further research. In the future, it is supposed to conduct re-research for all CRE teachers in southern Papua, considering that education must be comprehensive to all remote areas in this country. In addition, the dedication and performance of CRE teachers need to be appreciated by various elements in various ways. 


\section{References}

[1] Ismail, M. I. 2012. Faktor yang Mempengaruhi Prestasi Belajar Anak. Artikel. yang diakses dari http://m.google.com/gurupeneliti pada Sabtu, 16 April 2015 pukul 12.30 WIB.

[2] Widoyoko, S. E. P., \& Rinawat, A. (2012). Pengaruh kinerja guru terhadap motivasi belajar siswa. Cakrawala Pendidikan

[3] Rusman. (2011). Model-Model Pembelajaran: Mengembangkan Profesionalisme Guru. Jakarta: Rajawali Perss.

[4] Kapur, R. (2018). Factors Influencing the Student's Academic Performance in Secondary Schools in India.

[5] Mayer, J. D., Roberts, R. D., \& Barsade, S. G. (2012). Human abilities: Emotional intelligence. Annu. Rev. Psychol., 59, 507-536.

[6] Feng, L., \& Guo, Q. (2017). Beneficial effect of altruism on well-being among Chinese college students: The role of self-esteem and family socioeconomic status. Journal of Social Service Research, 43(3), 416-431.

[7] Barasch, A., Levine, E. E., Berman, J. Z., \& Small, D. A. (2014). Selfish or selfless? On the signal value of emotion in altruistic behavior. Journal of personality and social psychology, 107(3), 393.

[8] Barasch, A., Levine, E. E., Berman, J. Z., \& Small, D. A., ibid.

[9] Sarwono, S. W., \& Meinarno, E., A. (2012). Psikologi Sosial. Jakarta: Salemba Humanika.

[10] Mowday, R. T., Porter, L. W., \& Steers, R. M. (2013). Employee-organization linkages: The psychology o commitment, absenteeism, and turnover: Academic press.

[11] Srivastava, P. S. (2016). Spiritual intelligence: An overview International Journal of Multidisciplinary Research and Development, Volume 3;(Issue 3), 224-227.

[12] Sudarsih, E. F. N. P., Puspitasari, E. F. N., \& Setyanti, S. W. L. H. (2014). Emotional Intelligence, Spiritual Intelligence and Employee Performance: The Mediating Role of Work Motivation.

[13] Burhani, M., \& Laurens, H. (2013). Kamus ilmiah populer, Jombang: Lintas Media

[14] Iskandar. (22012). Psikologi Pendidikan, sebuah orientasi baru, Jakarta: Referensi.

[15] Petrides, K. V., \& Furnham, A. (2006). The Role of Trait Emotional Intelligence in a Gender-Specific Model of Organizational Variables 1. Journal of Applied Social Psychology, 36(2), 552-569.

[16] Brackett, M. A., Rivers, S. E., \& Salovey, P. (2011). Emotional intelligence: Implications for personal, social, academic, and workplace success. Social and Personality Psychology Compass, 5(1), 88-103.

[17] Brackett, M. A., Rivers, S. E., \& Salovey, P. Ibid.

[18] Tambe, S. (2014). A study of organizational citizenship behaviour (OCB) and its dimensions: a literature review.

[19] Cook, K. S., Cheshire, C., Rice, E. R., \& Nakagawa, S. (2013). Social exchange theory Handbook of social psychology (pp. 61-88): Springer.

[20] METE, E. S. (2019). The Relationship among Altruism, Affective Commitment, Job Satisfaction, and Turnover Intention: A Research on Boundary Spanning Positions in Hotel Enterprises. Journal of Tourism and Gastronomy Studies, 310, 327.

[21] Barasch, A., Levine, E. E., Berman, J. Z., \& Small, D. A. (2014). Selfish or selfless? On the signal value of emotion in altruistic behavior. Journal of personality and social psychology, 107(3), 393.

[22] Batson, C. D. (2014). The altruism question: Toward a social-psychological answer: Psychology Press.

[23] Agustian, A. G. (2001). Emotional spiritual quotient. Jakarta: Arga.

[24] Gayathri, N., \& Meenakshi, K. (2013). A literature review of emotional intelligence. International Journal of Humanities and Social Science Invention, 2(3), 42-51.

[25] Robbins. 2009. Organizational behavior. Salemba Empat, Jakarta.

[26] Dessler, G. (2009). Manajemen SDM Jakarta: Indeks. 
[27] Hair, J. F., Black, W. C., Babin, B. J., Anderson, R. E., \& Tatham, R. L. (2006). Multivariate data analysis . Uppersaddle River: NJ: Pearson Prentice Hall.

[28] Van Scotter, J. R. 2000. Relationships of task performance and contextual performance with turnover, job satisfaction, and affective commitment. Human resource management review, 10 (1): 79-95.

[29] Iskandar. (22012). Psikologi Pendidikan, sebuah orientasi baru, Jakarta: Referensi.

[30] Sahafi, E., Danaee, H., Sarlak, M., \& Haghollahi, F. (2011). The impact of emotional intelligence on citizenship behavior of physicians (with emphasis on infertility specialists). Journal of Family and Reproductive Health, 109-115.

[31] Tambe, S. (2014). A study of organizational citizenship behaviour (OCB) and its dimensions: a literature review.

[32] Srivastava, P. S. (2016). Spiritual intelligence: An overview International Journal of Multidisciplinary Research and Development, Volume 3;(Issue 3), 224-227. 